\title{
Isolated penile metastases secondary to invasive bladder cancer
}

\author{
Sam Hughes 도 , Antoine Kass-lliyya
}

Urology, Yorkshire and the Humber Postgraduate Deanery, York, UK

\section{Correspondence to} Dr Sam Hughes; sam.hughes2@nhs.net

Accepted 6 May 2021
Check for updates

(C) BMJ Publishing Group Limited 2021. No commercial re-use. See rights and permissions. Published by BMJ.

\begin{tabular}{l}
\hline To cite: Hughes S, \\
Kass-Iliyya A. BMJ Case \\
Rep 2021;14:e243673. \\
doi:10.1136/bcr-2021- \\
243673
\end{tabular}

\section{DESCRIPTION}

Penile metastases secondary to invasive bladder cancer are extremely rare. Globally, 127 cases have been documented, according to the latest comprehensive literature review. ${ }^{1}$ With an associated life expectancy of less than 1 year, this clinical presentation confers a very poor prognosis. However, treatment modalities including chemotherapy, radiotherapy and in a select number of cases, a total penectomy-have demonstrated conservative success. ${ }^{23}$ For symptom relief only, radical ablative surgery can also be considered. ${ }^{2}$

Although bladder and prostate cancer represent the primary source in the majority of cases $(60 \%)$, two other primaries of note beyond the urogenital tract include lung cancer $(18 \%)$ and colorectal cancer (17\%). ${ }^{1}$ However, the mechanism of spread to the penis is not fully understood as paradoxically, despite its rich vascular supply and generous lymphatic system, metachronous penile metastases remain incredibly uncommon. Although direct extension into the penile root has been hypothesised, the most prevalent theory is 'retrograde venous spread' between the pelvic and penile systems. ${ }^{12}$

Most men present, 18 months following their initial diagnosis, at a mean age of 65. Classically, they present with malignant priapism, however other common presentations include penile nodules, urinary retention and haematuria. ${ }^{2}$ For those presenting with palpable nodules, the vast majority are 'painless', occurring along the penile shaft, with only $12 \%$ affecting the glans penis. ${ }^{2}$ Moreover, most occur as part of widespread disseminated disease, rather than isolated to the penis.

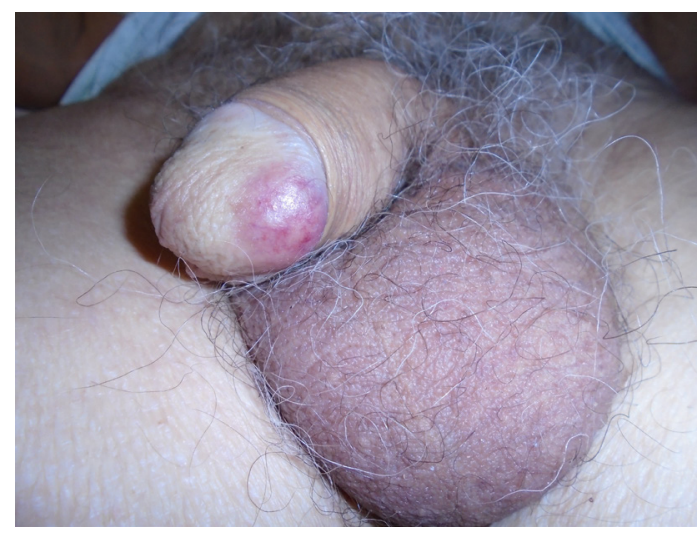

Figure 1 Photograph of presenting complaint: a raised, erythematous, painful lesion with $12 \mathrm{~mm}$ diameter located on the glans penis.

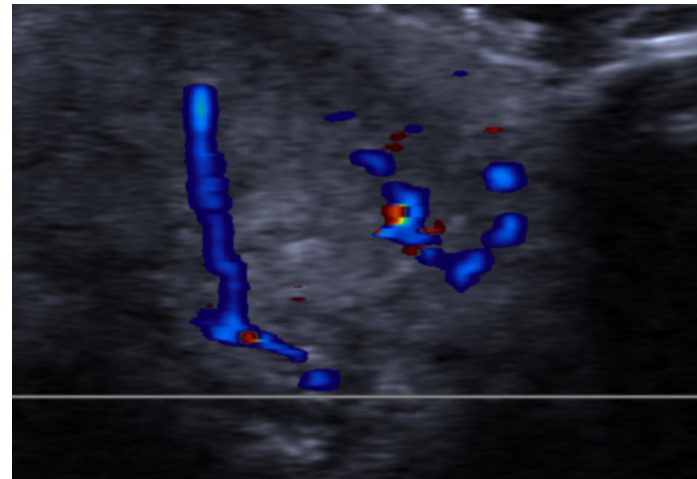

Figure 2 Ultrasound image (with Doppler) confirming 'a solid mass with internal vascularity consistent with metastatic disease with further soft tissue deposits along the penile shaft'.

Here, we present a case of a 91-year-old man, 1 month following his initial diagnosis of a muscle invasive bladder cancer (T4N0M0), who presented with a raised, erythematous, painful lesion on his glans penis (figure 1). Refractory to both local and systemic analgesia, he was primarily admitted for pain relief. He denied any trauma, haematuria, discharge or episodes of malignant priapism. Interestingly, on closer examination, there were additional, painless, firm nodules, palpable along the entire penile shaft.

A penile ultrasound scan confirmed 'a solid mass with internal vascularity consistent with metastatic disease with further soft tissue deposits along the penile shaft' (figure 2). Given the patient's age and comorbidities, conservative management with analgesia was deemed most appropriate, and thus, further investigations such as a penile MRI and histological sampling were not pursued.

When reviewing the patient's previous CT imaging, taken at the time of diagnosis, the tumour was reported as 'invading the posterior peri-vesical fat to abut the internal iliac artery'. Thus, without radiological evidence of local lymphatic spread or direct extension into the penile root, this report strongly suggests direct haematogenous spread.

In comparison to the current scientific literature, this case proves to be particularly interesting indeed. First, at 91 years old, this man was almost three decades more advanced than the mean age of presentation. Moreover, his presenting lesion was both painful and affecting the glans penis-two relatively atypical features of penile metastases. 
This case aims to raise awareness of penile metastases, which are often misdiagnosed given their rarity, wide spectrum of clinical presentations and ability to present as an isolated deposit, independent of the degree of dissemination of the primary tumour. In creating this awareness among clinicians, promotes

Learning points

Penile metastases secondary to invasive bladder cancer are extremely rare, with only 127 cases have been documented in scientific literature, worldwide.

- Penile metastases confer as associated life expectancy of less than 1 year.

- In the context of urological malignancies, a thorough penile examination should be conducted in order to assess for secondary spread. for earlier detection, which in a younger man-may confer moderate prognostic benefit.

Contributors $\mathrm{Dr}$ SH and Mr AK-L were directly involved in the care of this patient. $\mathrm{Dr}$ SH conducted the relevant literature review and wrote the case report. Under the guidance from the urology consultant Mr AK-L, the final edit was then completed.

Funding The authors have not declared a specific grant for this research from any funding agency in the public, commercial or not-for-profit sectors.

Competing interests None declared.

Patient consent for publication Obtained.

Provenance and peer review Not commissioned; externally peer reviewed.

\section{ORCID iD}

Sam Hughes http://orcid.org/0000-0002-3655-131X

\section{REFERENCES}

1 Chaux A, Amin M, Cubilla AL, et al. Metastatic tumors to the penis. Int I Surg Pathol 2011;19:597-606.

2 Zhu Y-P, Yao X-D, Zhang H-L, et al. Penile metastasis from primary bladder cancer: a study of 8 cases and review of the literature. Onkologie 2012;35:196-9.

3 Tayeh GA, Semaan A, Sarkis J, et al. Early penile-only metastasis of urothelial bladder carcinoma. Future Sci OA 2020;6:FSO611.

Copyright 2021 BMJ Publishing Group. All rights reserved. For permission to reuse any of this content visit

https://www.bmj.com/company/products-services/rights-and-licensing/permissions/

BMJ Case Report Fellows may re-use this article for personal use and teaching without any further permission.

Become a Fellow of BMJ Case Reports today and you can:

- Submit as many cases as you like

- Enjoy fast sympathetic peer review and rapid publication of accepted articles

- Access all the published articles

- Re-use any of the published material for personal use and teaching without further permission

Customer Service

If you have any further queries about your subscription, please contact our customer services team on +44 (0) 2071111105 or via email at support@bmj.com.

Visit casereports.bmj.com for more articles like this and to become a Fellow 